\title{
The Pluripotent Activities of Caffeic Acid Phenethyl Ester
}

\author{
Batoryna Olgierd ${ }^{1, * \mathbb{D}}, \dot{Z Z}_{\text {yła Kamila }}{ }^{1}$, Banyś Anna ${ }^{2}$ and Morawiec Emilia ${ }^{3,4,5}$ (D) \\ 1 Department of Community Pharmacy, Faculty of Pharmaceutical Sciences in Sosnowiec, Medical University \\ of Silesia in Katowice, 40-055 Katowice, Poland; kzyla@sum.edu.pl \\ 2 Department of Pharmaceutical Technology, Faculty of Pharmaceutical Sciences in Sosnowiec, Medical \\ University of Silesia in Katowice, 40-055 Katowice, Poland; abanys@sum.edu.pl \\ 3 Department of Microbiology, Faculty of Medicine in Zabrze, University of Technology in Katowice, \\ 40-555 Katowice, Poland; emilia.wojdas@gmail.com \\ 4 GynCentrum, Laboratory of Molecular Biology and Virology, 40-851 Katowice, Poland \\ 5 Department of Histology, Cytophysiology and Embryology in Zabrze, Faculty of Medicine in Zabrze, \\ University of Technology in Katowice, 40-555 Katowice, Poland \\ * Correspondence: blizniaka10@o2.pl or obatoryna@sum.edu.pl; Tel.: +48-602-689-347
}

check for

updates

Citation: Olgierd, B.; Kamila, Ż.;

Anna, B.; Emilia, M. The Pluripotent Activities of Caffeic Acid Phenethyl Ester. Molecules 2021, 26, 1335.

https://doi.org/10.3390/molecules 26051335

Academic Editor: Ioanna Chinou

Received: 27 January 2021

Accepted: 26 February 2021

Published: 2 March 2021

Publisher's Note: MDPI stays neutral with regard to jurisdictional claims in published maps and institutional affiliations.

Copyright: (C) 2021 by the authors Licensee MDPI, Basel, Switzerland. This article is an open access article distributed under the terms and conditions of the Creative Commons Attribution (CC BY) license (https:// creativecommons.org/licenses/by/ $4.0 /)$.

\begin{abstract}
Caffeic acid phenethyl ester (CAPE) is a strong antioxidant extracted from honey bee-hive propolis. The mentioned compound, a well-known NF-kB inhibitor, has been used in traditional medicine as a potent anti-inflammatory agent. CAPE has a broad spectrum of biological properties including anti-viral, anti-bacterial, anti-cancer, immunomodulatory, and wound-healing activities. This review characterizes published data about CAPE biological properties and potential therapeutic applications, that can be used in various diseases.
\end{abstract}

Keywords: caffeic acid phenethyl ester (CAPE); propolis; inflammation; antioxidant; NF- $\mathrm{B}$

\section{Introduction}

Propolis has been used in traditional medicine because of its wide spectrum of therapeutic benefits and its good historical safety profile. To date, more than 300 different compounds have been identified in propolis, including: aliphatic acids, esters, aromatic acids, fatty acids, carbohydrates, aldehydes, amino acids, ketones, chalcones, dihydrochalkones, terpenoids, vitamins and inorganic substances [1,2]. Caffeic acid phenethyl ester (CAPE) is one of the most promising bioactive ingredients found in propolis [3,4]. CAPE was identified as a component of propolis in 1987 and synthesized in 1988 at Columbia University [5]. Its molecular formula is $\mathrm{C}_{17} \mathrm{H}_{16} \mathrm{O}_{4}$ [3]. The structure of the compound is shown in Figure 1 [3]. CAPE is a polyphenol with hydroxyl groups in the catechol ring [6]. The presence of hydroxyl groups in the catechol ring is responsible for many of its biological activities [7]. CAPE has several biological properties including anti-inflammatory, antioxidant, anti-viral, anti-bacterial, immunomodulatory, anti-cancer and wound healing activities [5,8-25].

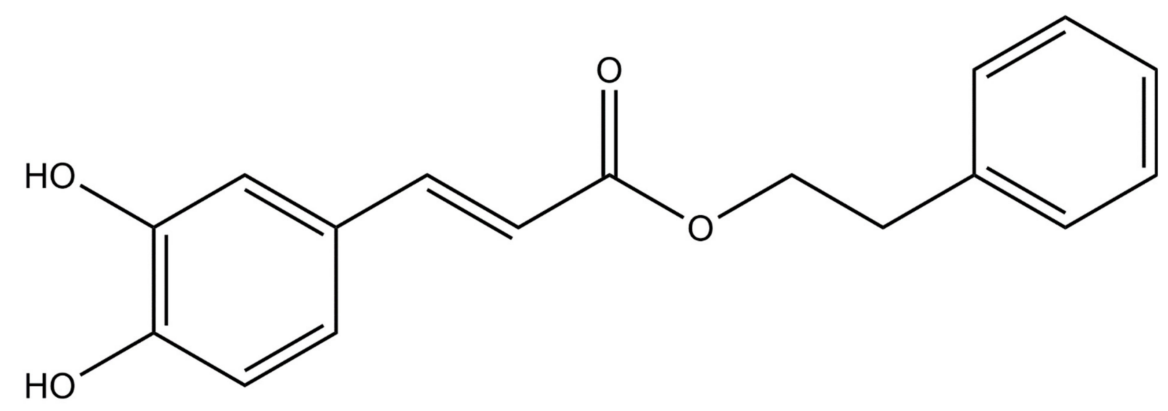

Figure 1. Chemical structure of caffeic acid phenethyl ester [3]. 


\section{Biological Properties}

\subsection{Anti-Inflammatory Properties}

CAPE has been described to conduct its anti-inflammatory activities by modulating different inflammatory pathways, including inhibition of the transcription factors NF- $\kappa B$ [25]. The NF- $\kappa B$ transcription factor plays a key role in a variety of physiological processes throughout the body, including immune responses, cell proliferation and inflammation [26]. NF-kB elicits its effects by promoting the transcription of many cytokines, chemokines, enzymes and antiapoptotic and cell growth factors [25].

NF- $\kappa B$ consists of homodimers and heterodimers from the Rel protein family, including p65/RelA, RelB, c-Rel, p50/p105 and p52/p100 [25,27,28]. Dysregulation of NF-kB and its dependent genes is associated with various pathological conditions including toxic/septic shock, graft versus host reaction, acute inflammatory conditions, acute phase response, viral replication, radiation damage, atherosclerosis, and cancer [29-31]. Activation of inactive NF- $\kappa$ B proteins present in the cytoplasm is induced by several factors, including pro-inflammatory cytokines (IL-1 and TNF- $\alpha$ ), bacterial products and protein synthesis inhibitors [32]. NF- $\mathrm{kB}$ is a protein complex that controls DNA transcription and is the central regulator of cellular stress in all cell types in humans. NF- $\mathrm{kB}$ plays a key role in regulating the immune response to infection as well as in acute and chronic inflammation [33]. Therefore, compounds that can affect the activation of the NF- $\mathrm{B}$ transcription factor have therapeutic potential because the activation of NF- $\kappa B$ is a critical step in the inflammatory cascade [34-37]. CAPE is potent and specific inhibitor of NF- $\mathrm{B}$ activation and this may provide the molecular basis for its multiple immunomodulatory and anti-inflammatory activities [26,37,38].

The NF- $\mathrm{B}$ p proteins are held in the cytoplasm in an inactive state by an inhibitory subunit called $\operatorname{IkB} \alpha$. The phosphorylation of $\operatorname{IkB} \alpha$ leads to the subsequent degradation of this protein and allows the translocation of NF- $k B$ to the nucleus [38-40]. Many agents, including inflammatory cytokines (IL-1, IL-6 and TNF- $\alpha$ ), enzymes (including nitric oxide synthase), adhesion molecules and acute-phase proteins, induce NF-кB [41-43]. CAPE has inhibitory effects on Helicobacter pylori-induced gastritis in Mongolian gerbils through the suppression of NF- $\kappa B$ activation and may thus have potential for prevention and therapy of Helicobacter pylori-associated gastric disorders [44]. CAPE suppressed Helicobacter pylori-induced NF- $\kappa$ B activation by inhibiting $I \kappa B \alpha$ degradation and $p 65$ phosphorylation in the gastric cancer cell line in a dose-dependent manner. Phosphorylation of $\mathrm{I} \kappa \mathrm{B} \alpha$ acts as a trigger of I $\kappa B$ degradation, allowing the nuclear translocation of NFKB complex and activation of gene expression. Some studies have shown that CAPE inhibits NF- $\mathrm{B}$ activation not by blocking the degradation of $\mathrm{IkB} \alpha$ but by suppressing the interaction of NF-kB proteins with DNA [24,25,45-50].

\subsection{Wound Repair}

Non-healing wounds are a large and growing "interdisciplinary" clinical problem. Therefore, there is a continuing need to develop new agents that accelerate the healing of acute and chronic wounds and ulcers. Modern methods of wound care are increasingly based on apitherapy, in which standardized, pharmacologically active fractions obtained from bee products are used. One such substance is propolis characterized by a documented, broad spectrum of biological activities that are potentially used in wound healing, i.e., antiseptic, anti-inflammatory, astringent, anesthetic and antioxidant activity [51-55]. These biological effects of propolis are necessary to accelerate the wound healing process $[51,54]$. The main components responsible for the biological activity of propolis are flavonoids, phenolic acids and their esters, such as the phenolic ester of caffeic acid described in this review [56].

Wound healing is the physiological response of the body that begins immediately after the appearance of the injury (Figure 2) [57]. The first stage hemostasis begins with narrowing of the damaged vessels [58]. Platelets are subject to adhesion, aggregation and activation, which leads to the formation of a blood clot that protects the structural 
integrity of the vessels and provides a temporary "scaffolding" enabling the formation of a temporary matrix in the wound bed. At the same time, cytokines, growth factors which interact with ECM components, are released into the wound bed, which initiates the repair process, preparing the damage bed for the next stage of the healing process, i.e., inflammation $[57,59]$. The inflammatory phase, which is initiated by neutrophils and develops under the influence of macrophages, is associated with cleaning the wound bed from bacteria and dead tissue debris, as well as releasing soluble mediators such as pro-inflammatory cytokines (IL-1, IL- 6, IL-8 and TNF- $\alpha$ ) and growth factors (PDGF, TGF- $\alpha$, TGF- $\beta$, IGF- 1 and FGF) responsible for the recruitment and activation of fibroblasts [57]. Lack of neutrophils, as well as a reduced number of macrophages in the wound environment indicate that the inflammatory phase is coming to an end and the proliferation phase begins [57]. After the hemostasis and inflammation phase, lasting 2-3 days, the process of rebuilding the damaged tissue intensifies [57]. During this time, the number of cells in the wound bed increases, which is associated with the migration and proliferation of fibroblasts and endothelial cells, as well as keratinocytes, which secrete a number of mediators that stimulate ECM biosynthesis, promoting epithelization and angiogenesis [57]. The temporary matrix, formed mainly from the fibrin and fibronectin networks, is replaced by a collagen matrix enriched in proteoglycans, glycosaminoglycans and non-collagen glycoproteins, which leads to the restoration of the structure and function of the proper tissue [57]. The key cells of the ECM biosynthesis phase are fibroblasts, which migrate to the site of damage within 48-72 $\mathrm{h}$ from the onset of injury [57], starting the synthesis of ECM components and the creation of new connective tissue with a characteristic "granular" appearance interlaced with many capillaries [57]. This tissue appears around the fourth day after injury [59,60]. It consists of collagen (mainly type I and III), elastin, proteoglycans, glycosaminoglycans and non-collagen proteins [57]. The consequence of ECM biosynthesis is epithelization. It is a multi-phase process which involves reconstruction of the epithelium after injury [57]. The epithelization process is followed by an angiogenesis stage in which new blood vessels are formed [61]. This process restores blood circulation at the site of damage and prevents the development of ischemic necrosis, while stimulating the process of tissue repair. Remodeling is the last phase of the healing process during which the wound surface shrinks [57]. During this phase of the healing process, granulation tissue "matures" into a scar, which is accompanied by an increase in the mechanical strength of the newly formed tissue [57].

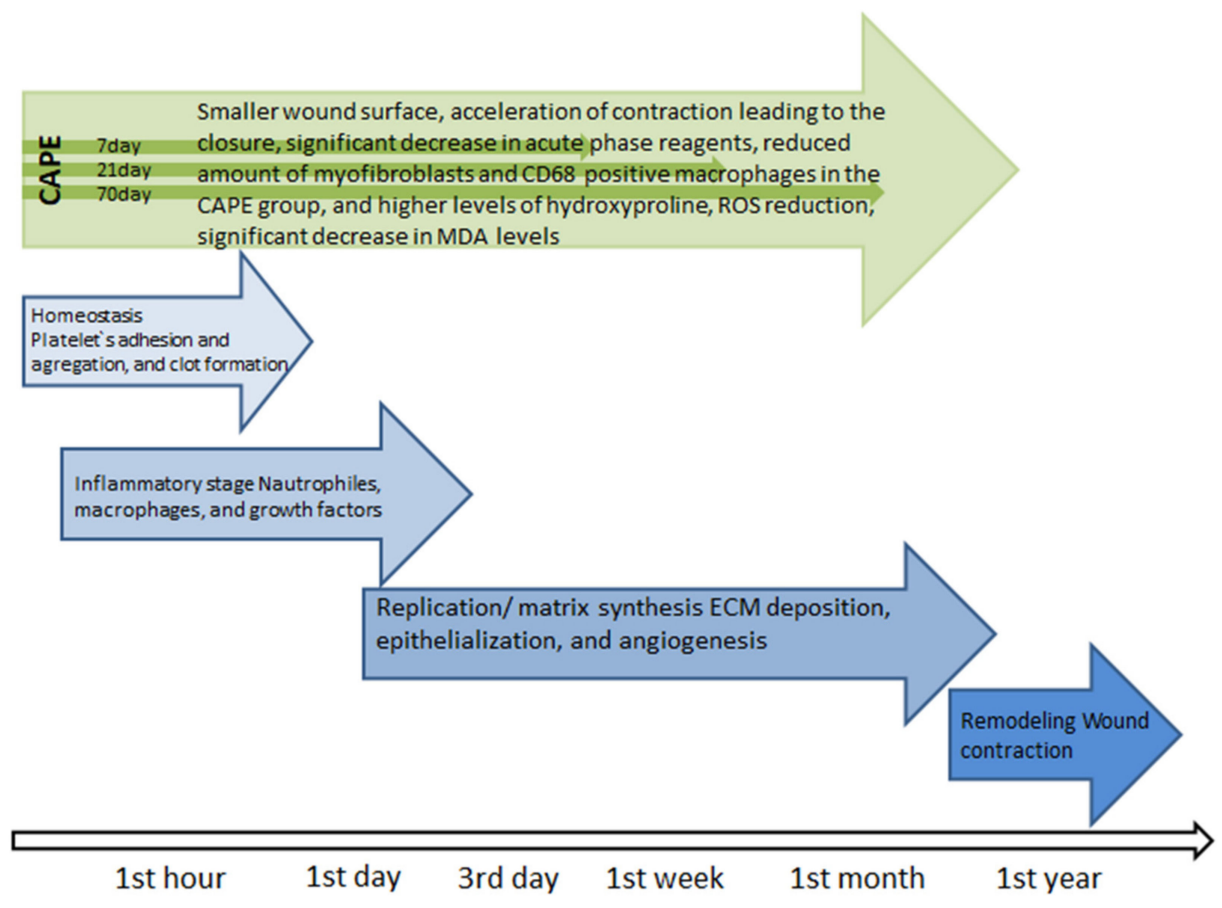

Figure 2. Healing stages [57]. 
Studies on the treatment of thermal burns in rats conducted with the use of CAPE showed macroscopically 7,21 and 70 days after the burn of a smaller wound surface and acceleration of contraction leading to the closure of the thermal damage to the skin in groups where CAPE was used compared to groups not supplied with the described compound. The positive effects of CAPE on the regeneration process of damaged skin in this study was also confirmed by biochemical analysis carried out 14 days after the burn. Analysis of myeloperoxidase activity showed a significant decrease in acute phase reagents. The nitric oxide determination showed a similar result. Tissue analysis 70 days after the burn also confirmed the long-term effect of CAPE, as it showed a reduced amount of myofibroblasts and CD68 positive macrophages in the CAPE group, and higher levels of hydroxyproline. These data show that the effect of CAPE on burn healing is still visible even after 70 days (CAPE administration stopped 14 days after the burn) [62]. Attention should be paid to some kind of modulation of proinflammatory mediator expression by CAPE used in wound healing. Studies in bedsores in mice have shown that the use of CAPE initially increased the expression of proinflammatory mediators (such as NOS2, TNF- $\alpha$ and NF- $k \mathrm{~B}$ ), infiltration of inflammatory cells, and oxidative damage (such as lipid peroxidation and peroxynitrite production). After 7 days, the expression of these parameters was reversed. This indicates the phenomenon of CAPE promoting early inflammatory response and associated oxidative stress as a short-term event, ultimately leading to accelerated healing of skin wounds and inhibition of inflammation and oxidative stress in the long term [19]. The process of treating damaged skin may hinder oxidative stress. CAPE has an antioxidant effect, thanks to which it can be widely used in the treatment of wounds of various origins, from minor skin abrasions to difficult-to-heal wounds such as burns, ulcers and pressure sores [63]. This is confirmed by studies on the effect of CAPE on the healing of skin wounds in rats, where a significant increase in the level of glutathione (GSH), which is an endogenous antioxidant and plays a key role in cellular defense in oxidative stress, has been shown in damaged CAPE-supplied tissues [63]. In the study, it was observed that GSH showed a progressive increase in the CAPE group, with significant differences on days 7 and 14, compared to the control group. CAPE, through its own antioxidant properties, can prevent GSH depletion. There was also a significant decrease in malondialdehyde (MDA) and superoxide dismutase activity in the CAPE group compared to the control group. Reactive oxygen species (ROS) are produced in response to skin damage and may cause cell damage by membrane lipid peroxidation, protein cross-linking and DNA breakdown. The study found a significant decrease in MDA levels in the CAPE group, especially on days 7 and 14 [63]. The multidirectional effect of CAPE in the form of free radical scavenging, anti-inflammatory and antimicrobial makes it an ideal candidate for the treatment of difficult-to-heal wounds of various origins.

\subsection{Antidiabetic Properties: Obesity}

CAPE can be useful in many pathological conditions caused by oxidative stress $[63,64]$. The increase in oxidative stress in diabetic patients is associated with a decrease in cellular antioxidant defense mechanisms. The transcription factor Nrf2 (nuclear factor-erythroid 2-related factor 2) is the main regulator of the body's antioxidant response by affecting the expression of hundreds of genes that promote many antioxidant/detoxifying enzymes. A strategy based on the pharmacological regulation of Nrf2 may be a target in the treatment of metabolic disorders such as diabetes mellitus [65]. Hyperglycemia induces an increase in the level of reactive oxygen species (ROS) and nitrogen species (RNS), which cause oxidative/nitroso stress and, consequently, tissue damage. Studies show that inducible nitric oxide synthase/gamma-glutamylcysteine ligase (iNOS/GGCL) and dimethylaminohydrolase (DDAH) dysregulation may play a key role in oxidative stress mediated by high glucose levels, while heme oxygenase-1 inductors (HO-1), such as CAPE or its stronger derivatives, may be useful in diabetes and other oxidative stress-related conditions [65]. An in vitro study in rats with type 1 diabetes induced with streptozotocin showed that $\mathrm{CAPE}$ and its analogues were $\mathrm{HO}-1$ inducers. Some of the compounds tested were stronger 
HO-1 inducers than CAPE. In particular, 2-(3,4-dihydroxyphenyl)-(2E)-2-propenoic acid (3,4-dimethoxyphenyl) ethyl ester (VP961) was the strongest. In addition, VP961 is the first known compound capable of directly activating HO- 1 and simultaneously inducing protein expression of this enzyme $[64,65]$. Other studies conducted in rats towards the use of CAPE in diabetes therapy have shown that caffeic acid phenethyl ester inhibits the enzyme 5-lipoxygenase already at micromolar concentrations, and alleviates diabetic atherosclerotic symptoms, which are a major macrovascular complication of diabetes, increasing the risk of myocardial infarction and stroke. CAPE has also been shown to inhibit the increase in serum TNF- $\alpha$ levels, induce HO-1 aortic expression, and reduce collagen deposition. CAPE administration virtually abolished diabetes-induced atherosclerosis symptoms without affecting developed hyperglycemia. These results suggest that CAPE may be an important apitherapeutic agent protecting the vascular system during diabetes [66].

Obesity is associated with numerous clinical disorders, such as hypertension, hyperglycemia, insulin resistance, endothelial dysfunction, elevated triglycerides and high cholesterol [67]. Adipocytes, are one of the main cells that build adipose tissue, produce a variety of biologically active molecules, including interleukins, TNF- $\alpha$, resistin, leptin, adiponectin, monocyte chemotactic protein (MCP-1), transforming growth factor (TGF- $\beta$ ), insulin-like growth factor (IGF-1) and C-reactive protein (CRP). Deregulation in the area of action of these factors leads to the general inflammation found in obesity [68]. CAPE has been shown to be effective in reducing acute inflammation induced by LPS in mature adipocytes derived from human ASC (Adipose Stem Cells) [67]. LPS is known to stimulate lipolysis. Excessive lipolysis contributes to the high level of circulating fatty acids and the development of insulin resistance-associated dyslipidemia seen in metabolic syndrome [69]. CAPE restores the function of adipocytes by increasing adiponectin and $\operatorname{PPAR} \gamma$ (Peroxisome proliferator-activated receptor gamma), which leads to the reduction of pro-inflammatory factors. PPAR $\gamma$ is the main gene regulator responsible for the involvement of adipocytes, and its activation leads to the improvement of insulin sensitivity [70]. Adiponectin represents the insulin sensitizing, anti-inflammatory and anti-apoptotic hormone released by functional adipocytes. Obesity is also accompanied by oxidative stress, characterized by increased formation of reactive oxygen species (ROS). As mentioned before, CAPE is a compound with a well-documented strong antioxidant effect. A preventive effect of CAPE on oxidative stress was observed during the differentiation of 3T3-L1 cells into adipocytes by inhibiting the production of reactive oxygen species and increasing the activity of superoxide dismutase inside the tested 3T3-L1 cells [71].

\subsection{Anti-Cancer Properties}

The mechanism of CAPE anti-tumor activity is complex and omni-directional. CAPE can express an anti-cancer effect by inhibiting DNA synthesis [15,71], interruption of growth signal transmission $[15,26]$, induction of apoptosis via an internal apoptotic pathway $[15,72-74]$, and promoting anti-angiogenic effects $[15,74,75]$. The potential use of such broad mechanisms of CAPE anti-tumor activity in cancer chemotherapy can be considered in several ways. Separately, when CAPE is the main active compound in planned chemotherapy or as a supplement to chemotherapy, or when CAPE is an adjuvant strengthening the anti-cancer effect of another active compound used in chemotherapy, and as a chemopreventive agent, it protects normal cells against the cytotoxic effects of anti-cancer drugs [76].

\subsubsection{CAPE as an Adjuvant}

Cancer chemotherapy requires the introduction of new solutions in the treatment regimen due to drug resistance, low effectiveness and many adverse effects of chemotherapeutic agents. Some tumors are internally resistant to many of the potent cytotoxic agents used in cancer therapy. Other cancers, initially sensitive, are not susceptible not only to the initially used therapeutic agents, but also to other drugs not used in the initial stages of therapy $[77,78]$. Combinations of drugs that interact with or complement each other 
with the anticipated therapeutic effect seem to be the right direction to conduct research to overcome problems associated with chemotherapy [15,70,79-81]. Modern medicine treats cancer using a combination of different treatment regimens. Therefore, substances of natural origin with documented anti-cancer activity have the potential as a complementary therapy in chemotherapy or radiation therapy. Many studies indicate the possibility of using CAPE as an adjuvant for a chemotherapeutic agent. CAPE treatment enhances the antitumor effect of cytostatic drugs, such as vinblastine, paclitacol, estramustine and docetaxel, used in the chemotherapy of prostate cancer [76,81,82]. Concomitant use of doxorubicin and cisplatin together with CAPE in gastric cancer has increased tumor sensitivity including chemo-resistant cancer cells, to cytostatics. CAPE increases the apoptotic cancer cell death induced by these two drugs by the accumulation of 4-hydroxy-2-nonenal (HNE), which is a highly reactive protein-bound aldehyde formed as a result of peroxidation by reactive oxygen species of membrane lipids [83]. CAPE inhibits HNE detoxifying enzymes (aldoketo reductase (1B1 and 1B10)) strongly expressed in gastric cancer cells, leading to HNE accumulation [84]. Reverse transcription-PCR analysis used in this mentioned study showed that CAPE treatment led to a reduction in the proteolytic activity of five proteasome subunits (PSMB1-PSMB5) and three immunoproteasome subunits (PSMB8PSMB10) in doxorubicin-resistant gastric cancer cells. This means that CAPE can be used as a valuable adjuvant in chemotherapy for doxorubicin and cisplatin in gastric cancer. CAPE may find a similar application as an adjunct to treatment in chemotherapy of lung cancer, where it increases the sensitivity of cancer cells to doxorubicin [85]. CAPE also enhances 5-fluorouracil-induced inhibition of oral cancer cell growth [84]. 5-fluorouracil is widely used in head and neck cancers; it has a large spectrum of side effects including diarrhea, nausea, vomiting, mouth ulceration, lack of appetite, watery eyes, photophobia, metallic taste in the mouth during infusion, and a decrease in blood cell counts. Co-treatment of the TW2.6 cell line of the oral squamous cell carcinoma with CAPE and 5-fluorouracil showed additive inhibition of cell proliferation $[86,87]$. Due to the location of oral cancer, 5 -fluorouracil is administered topically in the form of a cream or solution directly on skin lesions. Incorporation of CAPE into 5-fluorouracil topical therapy against oral cancer may reduce the amount and severity of side effects during chemotherapy. An additional advantage of using a lower concentration of the anti-cancer drug in addition to affecting the side effects is the reduction in the cost of therapy, which in the case of cancer chemotherapy is exceptionally large [86]. The combination of tamoxifen and CAPE applied against the human breast cancer cell line MCF-7 showed a synergistic cytotoxic effect manifested by significant activation of apoptotic mechanisms, along with a decrease in Bcl-2 protein and beclin-1 protein [88]. An additional benefit of the combination of CAPE + tamoxifen is the possibility, as in the case of 5-fluorouracil, to use a lower concentration of both drugs, which is particularly important due to the numerous side effects of anti-cancer drugs and the high cost of therapy. This has been confirmed by studies with the simultaneous use of tamoxifen and CAPE in breast cancer. Both tamoxifen and CAPE disrupt the antioxidant system in cancer cells by acting as pro-oxidants, stimulating apoptosis from excess reactive oxygen species. It should also be noted that only CAPE acts selectively on diseased cells, without adversely affecting normal cells [88].

\subsubsection{Chemoprevention}

The interaction of anticancer drugs with substances of natural origin such as CAPE may be useful as support for cancer therapy in terms of chemoprevention of non-cancerous cells $[86,88,89]$. CAPE, in contrast to tamoxifen, proapoptotically affects only cancer cells, without affecting healthy, non-cancer cells. As a result, it does not have the side effects that are characteristic of anti-cancer drugs. The CAPE tamoxifen tandem prolonged the life of animals with Ehrlich tumor and caused a marked regression of tumor size and weight compared to animals treated with tamoxifen or CAPE only [88]. 


\subsubsection{Effect on Angiogenesis and Metastasis}

Angiogenesis, the formation of new blood vessels, is an essential step in the progression of cancer, which allows the supply of nutrients and oxygen, as well as the removal of side products from cancer-changed tissues. In addition, newly formed blood vessels are the gateway to the expansion of cancer cells and the formation of metastases in other tissues and organs $[90,91]$. The regulation of tumor angiogenesis depends on the balance between angiogenic and anti-angiogenic factors produced within the pathological microenvironment. Disorders of this process lead to tumor angiogenesis. VEGF (vascular endothelial growth factor) acts as a strong angiogenic factor in pathological angiogenesis, it is secreted from tumor cells within the tumor, increasing its growth and contributing to metastasis. In addition, VEGF is necessary for the migration, permeability and proliferation of endothelial cells in the process of pathological angiogenesis. A significantly higher concentration of VEGF was observed in the regions of richly vascularized malignant tumors. Patients with elevated serum VEGF levels had a worse prognosis compared to patients with low VEGF levels. It is known that VEGF and its VEGFR-2 receptor, also called KDR, are required for the formation of new capillaries from pre-existing blood vessels in cancerous tissues. They play an important role in tumor progression, causing tumor growth, invasion and metastasis $[92,93]$. CAPE inhibits the VEGF-induced VEGFR-2 signaling pathway by suppressing VEGFR-2 tyrosine phosphorylation in endothelial cells. The inhibitory effects of CAPE on VEGF/VEGFR-2-dependent angiogenesis not only affect tumor growth but also endothelial cell activation [22]. Confirmation of the beneficial effects of CAPE on tumor mass and tumor size were studied in mice with Ehrlich tumor. The combined use of tamoxifen and CAPE resulted in the highest life expectancy of the mice and the lowest values of tumor size and mass [74]. CAPE controls tumor growth by stimulating angiostatic factors and inhibiting angiogenic factors whose expression deviates from physiological balance [94]. It has been suggested that blocking signaling by the NF-kB transcription factor inhibits angiogenesis and carcinogenicity in various types of cancer cells by suppressing VEGF expression $[88,95,96]$. CAPE, by inhibiting the NF- $\mathrm{KB}$ nuclear factor in human MCF-7 breast cancer cells, inhibits VEGF expression, and thus angiogenesis $[88,94,96]$. CAPE treatment reduces vascular endothelial growth factor (VEGF) secretion by inhibiting the ROS, PI3K and HIF- $1 \alpha$ signaling pathways in human retinal pigment epithelial cells under hypoxia $[86,97]$.

Tumor metastases include ECM degradation [86,98], which is regulated by matrix metalloproteinases (MMPs) [86,99]. The MMP gene is expressed in response to stimulation by several pro-inflammatory cytokines such as TNF- $\alpha$, interleukin (IL) $-1 \beta$ and IL-6. MMP activity is regulated by several types of inhibitors, among which metalloproteinase tissue inhibitors (TIMPs) are the most important [100-102]. The balance between MMP and TIMP is responsible for controlling ECM protein degradation. MMP-2 and MMP-9 are the main enzymes involved in ECM degradation [103,104]. CAPE exerts an inhibitory effect on the expression and activity of MMP-2 by upregulating TIMP-2 and strongly reduces migration by reducing the focal phosphorylation of adhesive kinase (FAK) and the activation of its further p38 signaling molecules, mitogen activated protein kinases (p38 MAPK) and $\mathrm{N}$-kinase final c-Jun (JNK) [105]. These data indicate that CAPE can potentially be used to prevent metastasis of oral cancer and that CAPE anti-tumor activity is at least partly regulated by the tumor microenvironment [86].

Both mRNA and COX-2 protein levels (present in inflamed sites) are strongly upregulated in OSCC (oral squamous cell carcinoma) $[86,106]$ and high-risk precancerous lesions [87,107]. Increasing COX-2 regulation correlates with higher lymph node metastases, faster cell proliferative activity, and poorer survival rates in patients with oral cancer $[88,108]$. Treatment of CAPE $35-70 \mu \mathrm{M}$ inhibits COX-2 activity and expression in human squamous cell carcinoma cells $1483[86,109]$. 


\subsection{New Directions of Application}

The therapeutic efficacy of CAPE was studied in rats with experimental endotoxininduced periodontitis. Osteoclastic bone resorption is conjugated to an increase in RANKL, which causes destruction of follicular bone in periodontitis. To analyze follicular bone loss, RANKL activation was evaluated. Histological analyzes revealed lower RANKL levels in the CAPE treated group than in the saline group $[110,111]$. This result may be associated with the anti-osteoclastic effect of CAPE by suppressing RANKL-induced osteoclastogenesis, thereby inhibiting follicular bone loss. As a result, these findings confirmed that CAPE $[110,112,113]$ improves bone healing, prevents RANKL-induced osteoclastogenesis, and can be used as a regenerative agent in bone resorption therapy.

CAPE demonstrated in dementia research an improvement in memory and prevention of memory impairment by enhancing antioxidant protection as a result of increased GSH (reduced glutathione) levels in rat brains. Reduced glutathione is the basic protection of the brain against oxidative stress and is used as a biomarker of oxidative stress [114].

\section{Conclusions}

The global demand for therapeutic alternatives in cancer therapy means that more effective and cheaper chemotherapeutic drugs are still being sought. Therefore, combinations of chemotherapeutic drugs with substances of natural origin with documented anti-cancer effects such as CAPE give hope for optimistic results. The combined use of CAPE together with anti-cancer drugs can be an important element in the design of a comprehensive anti-cancer therapy strategy, covering both the aspect of treating the cancer itself through the use of the synergistic cytotoxic effect of CAPE and anti-cancer drugs, as well as equally important in the chemoprevention of non-cancerous cells exposed to adverse side effects of anti-cancer drugs [115]. Table 1 presents a wide spectrum of CAPE effects.

Table 1. Reported CAPE effects.

\begin{tabular}{|c|c|}
\hline Effect & Reference \\
\hline \multicolumn{2}{|c|}{ Anti-Inflammatory Properties } \\
\hline Cells and neurons protection in acute septic shock & Korish and Arafa., 2011 [9] \\
\hline Corneal neovascularization & Totan et al., 2001 [14] \\
\hline Inhibition of thrombin activity & Melzig and Henke., 2005 [16] \\
\hline Slowing the progression of amyotrophic lateral sclerosis & Fontanilla et al., 2012 [18] \\
\hline Improved solubility and anti-inflammatory effect through transglycosylation & Li et al., 2019 [24] \\
\hline NF- $\kappa B$ pathway regulation & $\begin{array}{c}\text { Natarajan et al., } 1996 \text { [26] } \\
\text { Wang et al., } 2010 \text { [31] } \\
\text { Linard et al., } 2004 \text { [32] } \\
\text { Choi and Choi., } 2008 \text { [35] } \\
\text { Orban et al., } 2000 \text { [36] } \\
\text { Lee et al., 2010 [41] } \\
\text { Jung et al., } 2008 \text { [43] } \\
\text { Toyoda et al., } 2009 \text { [44] } \\
\text { Bezerra et al., } 2012 \text { [46] } \\
\text { Andrade-Silva et al., } 2009 \text { [49] } \\
\text { K1zildağ et al., } 2019 \text { [110] } \\
\text { Tambuwala et al., } 2019 \text { [116] }\end{array}$ \\
\hline Reduction in the development of atherosclerosis & Hishikawa et al., 2005 [30] \\
\hline Protection of cerebellar granular neurons against neurotoxicity & Wei et al., $2008[1]$ \\
\hline Protective effect on hepatic ischemia/reperfusion injury & Saavedra-Lopes et al., 2008 [38] \\
\hline Inhibition of nitric oxide synthase & Song et al., 2002 [45] \\
\hline Anti-inflammatory effect on endotoxin-induced uveitis & Ylmaz et al., 2005 [50] \\
\hline Inhibition of cyclooxygenase-2 & Michaluart et al., 1999 [109] \\
\hline Prevention of dementia & Kumar et al., 2017 [114] \\
\hline Hypoxia-inducible transcription factor regulation & Bhargava et al. 2018 [7] \\
\hline
\end{tabular}


Table 1. Cont.

\begin{tabular}{|c|c|}
\hline Effect & Reference \\
\hline \multicolumn{2}{|c|}{ Wound Repair } \\
\hline Regeneration of burns & Dos Santos et al., 2013 [19] \\
\hline Healing pressure ulcers & Romana-Souza et al., 2018 [62] \\
\hline Accelerating skin wound healing & Serarslan et al., 2007 [63] \\
\hline Bone treatment & Kazancioglu et al., 2015 [112] \\
\hline \multicolumn{2}{|c|}{ Anti-Diabetic Properties } \\
\hline Anti-diabetic effect & Abduljawad et al., 2013 [42] \\
\hline Protective effect in type 1 diabetes & Sorrenti et al., 2019 [65] \\
\hline Alleviation of diabetic atherosclerosis & Hassan et al., 2014 [66] \\
\hline \multicolumn{2}{|c|}{ Obesity } \\
\hline Regulation of PPAR levels in adipocytes & Vanella et al., 2016 [67] \\
\hline Inhibition of oxidative stress in adipocytes & Yasui et al., 2013 [71] \\
\hline \multicolumn{2}{|c|}{ Anti-Cancer Properties } \\
\hline Cytotoxic effect on cancer cells & $\begin{array}{c}\text { Grunberger et al., } 1998 \text { [5] } \\
\text { Watanabe et al., } 2011 \text { [8] } \\
\text { Kabała-Dzik et al., } 2017 \text { [55] }\end{array}$ \\
\hline Pro-apoptotic effect on cancer cells & $\begin{array}{c}\text { Hung et al., } 2003 \text { [11] } \\
\text { Jin et al., } 2008 \text { [37] } \\
\text { Chen et al., } 2008 \text { [73] } \\
\text { Gherman et al., } 2016 \text { [78] }\end{array}$ \\
\hline Restoration of gap junctional intercellular communication & Na et al., 2000 [17] \\
\hline Chemoprevention & Carrasco-Legleu et al., 2004 [47] \\
\hline Inhibition of tumor promotion & $\begin{array}{l}\text { Huang et al., } 1996 \text { [72] } \\
\text { Imai et al., } 2019 \text { [23] } \\
\text { Lin et al., 2012 [81] } \\
\text { Kuo et al., } 2015 \text { [86] } \\
\text { Chuu et al., 2012 [89] } \\
\text { El-Refaei et al., } 2010 \text { [94] }\end{array}$ \\
\hline Effect on the proteasome & Peng et al., 2012 [105] \\
\hline Cytotoxic adjuvant & $\begin{array}{l}\text { Matsunaga et al., } 2019 \text { [76] } \\
\text { Tolba et al., } 2013 \text { [82] } \\
\text { Sonoki et al., } 2018 \text { [85] } \\
\text { Kuo et al., 2013 [87] } \\
\text { Motawi et al., } 2016 \text { [88] }\end{array}$ \\
\hline Inhibition of human aldo-keto reductase & Soda et al., 2012 [84] \\
\hline \multicolumn{2}{|c|}{ Effect on Angiogenesis } \\
\hline Inhibition of angiogenesis & $\begin{array}{l}\text { Song et al., } 2002 \text { [12] } \\
\text { Paeng et al., } 2015 \text { [97] }\end{array}$ \\
\hline Inhibition of VEGFR-2 activation & Chung et al., 2013 [22] \\
\hline
\end{tabular}

Despite the enormous advantages of CAPE, there are several issues that may cause problems with the actual implementation of this compound in practical medicine. Due to the phenolic nature of $\mathrm{CAPE}$, it exhibits a large spectrum of biological activities that can be used in various disease entities, but it has low solubility, and thus poor bioavailability, which significantly limits its effectiveness and requires the use of high doses [115]. Problems with solubility and bioavailability can be overcome by introducing modern drug delivery systems, e.g., using albumin nanoparticles, providing better therapeutic effects at a lower dose [116]. Another problem that may be significant is the allergenic properties of propolis. It has been reported that $1.2-6.6 \%$ of patients with dermatitis are sensitive to propolis. CAPE obtained from propolis could be a potential source of allergies, so that patients with allergic predisposition could be exposed to an increased risk of side effects, 
although this requires more careful examination in the future [117,118]. Difficult-to-heal wounds, such as burns, ulcers or pressure ulcers, remain an essentially unsolved medical problem, therefore there is a constant need to search for new effective solutions in this area. Standardized, pharmacologically active fractions obtained from bee products, such as propolis and one of its most biologically active ingredients, CAPE, are characterized by scientifically proven, multidirectional action in the field of wound healing of various origins, being a significant support for newly designed solutions in this process. This is confirmed by numerous scientific studies, including our authorship, describing their impact on the wound healing process. One of our newest studies confirming the reparative and regenerative properties of propolis, and thus also CAPE, is the use of electron paramagnetic resonance spectroscopy (EPR) to determine paramagnetic centers occurring in blood samples taken from experimental animals, after the application of therapy with an innovative biodegradable propolis-nanofiber dressing [119]. Paramagnetic centers and changes in free radicals indicate the beneficial effect of the innovative combination of nanofibers with a natural ingredient with a broad spectrum of action, i.e., propolis, on the process of burn regeneration. The multifaceted influence of propolis on changes in the pro-oxidative-antioxidant balance, the components of which play a fundamental role in the repair of tissue damage, indicates the high potential of antioxidant compounds, including propolis, in accelerating wound healing, including thermal burns [119]. The above-mentioned observations confirm our previous research, which showed that the concentration of free radicals in the matrix of wounds treated with propolis was much lower than in the case of wounds treated with a standard drug-silver sulfadiazine, which is associated with the creation of a favorable biochemical environment by propolis supporting the wound healing process $[52,56]$.

The pleiotropic effect of the caffeic acid phenethyl ester gives a wide range of therapeutic possibilities in many disease entities, in which CAPE has not been used so far, e.g., dementia or bone resorption. Therefore, this active compound will remain the subject of much future research. Human research needs to be significantly expanded as most research on CAPE is based on animal and in vitro studies.

Author Contributions: Conceptualization, B.O.; Writing-original draft, B.O. and Ż.K.; Review and Editing, M.E.; Supervision, B.A.; All authors have read and agreed to the published version of the manuscript.

Funding: This research received no external funding.

Data Availability Statement: Data sharing is not applicable. No new data were created or analyzed in this study.

Conflicts of Interest: The authors declare that there are no conflicts of interest.

\section{References}

1. Wei, X.; Ma, Z.; Fontanilla, C.V.; Zhao, L.; Xu, Z.C.; Taggliabraci, V.; Johnstone, B.H.; Dodel, R.C.; Farlow, M.R.; Du, Y. Caffeic acid phenethyl ester prevents cerebellar granule neurons (CGNs) against glutamate-induced neurotoxicity. Neuroscience 2008, 155, 1098-1105. [CrossRef]

2. Ryoo, S.W.; Kim, D.U.; Won, M.; Chung, K.S.; Jang, Y.J.; Oh, G.T.; Park, S.K.; Maeng, P.J.; Yoo, H.S.; Hoe, K.L. Native LDL induces inerleukin-8 expression via $\mathrm{H} 2 \mathrm{O} 2$, p38 Kinase, and activator protein-1 in human aortic smooth muscle cells. Cardiovasc. Res. 2004, 62, 185-193. [CrossRef]

3. Available online: https:// pubchem.ncbi.nlm.nih.gov/compound/Caffeic_acid_phenethyl_ester\#section=2D-Structure (accessed on 20 December 2020).

4. Tolba, M.F.; Azab, S.S.; Khalifa, A.E.; Abdel-Rahman, S.Z.; Abdel-Naim, A.B. Caffeic acid phenethyl ester, a promising component of propolis with a plethora of biolobical activities: A review on its anti-inflammatory, neuroprotective, hepatoprotective, and cardioprotective effects. IUBMB Life 2013, 65, 699-709. [CrossRef] [PubMed]

5. Grunberger, D.; Banerjee, R.; Eisinger, K.; Oltz, E.M.; Efros, L.; Caldwell, M.; Estevez, V.; Nakanishi, K. Preferential cytotoxicity on tumor cells by caffeic acid phenethyl ester isolated from propolis. Experientia 1998, 44, 230-232. [CrossRef]

6. Murtaza, G.; Karim, S.; Akram, M.R.; Khan, S.A.; Azhar, S.; Mumtaz, A.; Asad, M.H.H.B. Caffeic Acid Phenethyl Ester and Therapeutic Potentials. Biomed. Res. Int. 2014, 2014, 145342. [CrossRef] 
7. $\quad$ Bhargava, P.; Kumari, A.; Putri, J.F.; Ishida, Y.; Terao, K.; Kaul, S.C.; Sundar, D.; Wadhwa, R. Caffeic acid phenethyl ester (CAPE) possesses pro-hypoxia and anti-stress activities: Bioinformatics and experimental evidences. Cell Stress Chaperones. 2018, 23, 1055-1068. [CrossRef]

8. Watanabe, M.A.; Amarante, M.K.; Conti, B.J.; Sforcin, J.M. Cytotoxic constituents of propolis inducing anticancer effects: A review. J. Pharm. Pharmacol. 2011, 63, 1378-1386. [CrossRef]

9. Korish, A.A.; Arafa, M.M. Propolis derivatives inhibits the systemic inflammatory response and protect hepatic and neuronal cells in acute septic shock. Braz. J. Infect. Dis. 2011, 15, 332-338. [CrossRef]

10. Coussens, L.M.; Werb, Z. Inflammation and cancer. Nature 2002, 420, 860-867. [CrossRef] [PubMed]

11. Hung, M.W.; Shiao, M.S.; Tsai, L.C.; Chang, G.G.; Chang, T.C. Apoptotic effect of caffeic acid pnenethyl ester and its ester and amide analogues in human cervical cancer ME180 cells. Anticancer Res. 2003, 23, 4773-4780.

12. Song, Y.S.; Park, E.H.; Jung, K.J.; Jin, C. Inhibition of angiogenesis by propolis. Arch. Pharm. Res. 2002, 25, 500-504. [CrossRef]

13. Ceschel, G.C.; Maffei, P.; Sforzini, A.; Lombardi Borgia, S.; Yasin, A.; Ronchi, C. In vitro permeation through porcine buccal mucosa of caffeic acid pnenethyl ester (CAPE) from a topical mucoadhesive gel containing propolis. Fitoterapia 2002, 73, S44-S52. [CrossRef]

14. Totan, Y.; Aydin, E.; Cekic, O.; CihanDagloglu, M.; Borazan, M.; Daglioglu, K.; Gultek, A. Effect of caffeic acid pnenethyl ester on corneal neovascularization in rats. Curr. Eye. Res. 2001, 23, 291-297. [CrossRef]

15. Chan, G.C.; Cheung, K.W.; Sze, D.M. The immunomodulatory and anticancer properties of propolis. Clin. Rev. Allergy Immunol. 2013, 44, 262-273. [CrossRef]

16. Melzig, M.F.; Henke, K. Inhibition of thrombin activity by selected natural products in comparison to neutrophil elastase. Planta. Med. 2005, 71, 787-789. [CrossRef] [PubMed]

17. Na, H.K.; Wilson, M.R.; Kang, K.S.; Chang, C.C.; Grunberger, D.; Trosko, J.E. Restoration of gap junctional intercellular communication by caffeic acid phenethyl ester (CAPE) in ras-transformed rat liver epithelial cell line. Cancer Lett. 2000, 157, 31-38. [CrossRef]

18. Fontanilla, C.V.; Wei, X.; Zhao, L.; Johnstone, B.; Pascuzzi, R.M.; Farlow, M.R.; Du, Y. Caffeic acid phenethyl ester extends survival of a mouse model of amyotrophic lateral sclerosis. Neuroscience 2012, 205, 185-193. [CrossRef]

19. Dos Santos, J.S.; Monte-Alto-Costa, A. Caffeic Acid Phentphyl Ester Improves Burn Healing in Rats Through Anti-Inflammatory and Antioxidant Effects. J. Burn Care Res. 2013, 34, 682-688. [CrossRef]

20. Lu, D.Y.; Huang, B.R.; Yeh, W.L.; Lin, H.Y.; Huang, S.S.; Liu, Y.S.; Kuo, Y.H. Antineuroinflammatory Effect of a Novel Caffeamide Derivative, KS370G, in Microglial cells. Mol. Neurobiol. 2013, 48, 863-874. [CrossRef] [PubMed]

21. Sun, L.P.; Chen, A.L.; Hung, H.C.; Chien, Y.H.; Huang, J.S.; Huang, C.Y.; Chen, Y.W.; Chen, C.N. Chrysin: A histone deacetylase 8 inhibitor with anticancer activity and a siutable candidate for the standardization of Chinese propolis. J. Agric. Food Chem. 2012, 60, 11747-11758. [CrossRef]

22. Chung, T.W.; Kim, S.J.; Choi, H.J.; Kwak, C.H.; Song, K.H.; Suh, S.J.; Kim, K.J.; Ha, K.T.; Park, Y.G.; Chang, Y.C.; et al. CAPE suppressses VEGFR-2 activation, and tumor neovascularization and growth. J. Mol. Med. (Berl). 2013, 91, 271-282. [CrossRef]

23. Imai, M.; Yokoe, H.; Tsubuki, M.; Takahashi, N. Growth inhibition of human breast and prostate cancer cells by cinnamic acid derivatives and their mechanism of action. Biol. Pharm. Bull. 2019, 42, 1134-1139. [CrossRef] [PubMed]

24. Li, Y.; Liu, L.H.; Yu, X.Q.; Zhang, Y.X.; Yang, J.W.; Hu, X.Q.; Zhang, H.B. Transglycosylation Improved Caffeic Acid Phenethyl Ester Anti-Inflammatory Activity and Water Solubility by Leuconostocmesenteroides Dextransucrase. J. Agric. Food Chem. 2019, 17, 4505-4512. [CrossRef]

25. Armutcu, F.; Akyol, S.; Ustunsoy, S.; Turan, F.F. Therapeutic potential of caffeic acid phenethyl ester and its anti-inflammatory and immunomodulatory effects. Exp. Ther. Med. 2015, 9, 1582-1588. [CrossRef] [PubMed]

26. Natarajan, K.; Singh, S.; Burke, T.R., Jr.; Grunberger, D.; Aggarwal, B.B. Caffeic acid pnenethyl ester is a potent and specific inhibitor of activation of nuclear transcription factor NF-kappaB. Proc. Natl. Acad. Sci. USA 1996, 20, 9090-9095. [CrossRef]

27. Ghosh, S.; May, M.J.; Kopp, E.B. NF-kappa B and Rel proteins: Evolutionarily conserved mediators of immune responses. Annu. Rev. Immunol. 1998, 16, 225-260. [CrossRef]

28. Chen, F.; Castranova, V.; Shi, X.; Demers, L.M. New insights into the role of nuclear factor-kappaB, a ubiquitous transcription factor in the initiation of diseases. Clin. Chem. 1999, 45, 7-17. [CrossRef] [PubMed]

29. Chen, Y.C.; Sosnoski, D.M.; Gandhi, U.H.; Novinger, L.J.; Prabhu, K.S.; Mastro, A.M. Selenium modifies the osteoblast inflammatory stress response to bone metastatic breast cancer. Carcinogenesis 2009, 30, 1941-1948. [CrossRef] [PubMed]

30. Hishikawa, K.; Nakaki, T.; Fujita, T. Oral flavonoid supplementation attenuates atherosclerosis development in apolipoprotein E-deficient mice. Arteriooscler. Thromb. Vasc. Biol. 2005, 25, 442-446. [CrossRef]

31. Wang, L.C.; Chu, K.H.; Liang, Y.C.; Lin, Y.L.; Chiang, B.L. Caffeic acid phenethyl ester inhibits nuclear factor-kappaB and protein kinase B signalling pathways and induces caspase-3 expression in primary human CD4+ T cells. Clin. Exp. Immunol. 2010, 160, 223-232. [CrossRef]

32. Linard, C.; Marquette, C.; Mathieu, J.; Pennequin, A.; Clarencon, D.; Mathe, D. Acute inducton of inflammatory cytokine expression after gamma-irradiation in the rat: Effect of an NF-kappaB inhibitor. Int. J. Radiat. Oncol. Biol. Phys. 2004, 58, 427-434. [CrossRef]

33. Tak, P.P.; Firestein, G.S. NF-kappaB: A key role in inflammatory diseases. J. Clin. Invest. 2001, 107, 7-11. [CrossRef] 
34. Bonizzi, G.; Karin, M. The two NF-kappaB activation pathways and their role in innate and adaptive immunity. Trends Immunol. 2004, 25, 280-288. [CrossRef]

35. Choi, K.; Choi, C. Differential regulation of c-Jun N-terminal kinase and NF-kappaB Pathway by caffeic acid phenethyl ester in astroglial and monocytic cells. J. Neurochem. 2008, 105, 557-564. [CrossRef]

36. Orban, Z.; Mitsiades, N.; Burke, T.R., Jr.; Tsokos, M.; Chrousos, G.P. Caffeic acid pnenethyl ester induces leukocyte apoptosis, modulates nuclear factor-kappa B and suppresses acute inflammation. Neuroimmunomodulation 2000, 7, 99-105. [CrossRef]

37. Jin, U.H.; Song, K.H.; Motomura, M.; Suzuki, I.; Gu, Y.H.; Kang, Y.J.; Moon, T.C.; Kim, C.H. Caffeic acid phenethyl ester induces mitochondria-mediated apoptosis in human myeloid leukemia U937 cells. Mol. Cell. Biochem. 2008, 210, 43-48. [CrossRef] [PubMed]

38. Saavedra-Lopes, M.; Ramalho, F.S.; Ramalho, L.N.; Andrade-Silva, A.; Martinelli, A.L.; Jordao, A.A., Jr.; Castro-e-Silva, O.; Zucoloto, S. The protective effect of CAPE on hepatic ischemia/reperfusion injury in rats. J. Surg. Res. 2008, 150, 271-277. [CrossRef] [PubMed]

39. Cao, Q.; Kaur, C.; Wu, C.Y.; Lu, J.; Ling, E.A. Nuclear factor-kappa B regulates Notch signaling in production of proinflammatory cytokines and nitric oxide in murine BV-2 microglial cells. Neuroscience 2011, 192, 140-154. [CrossRef] [PubMed]

40. Joo, J.H.; Jetten, A.M. NF-kappaB-dependent transcritionl activation in lung carcinoma cells by farnesol involves p65/RelA(Ser276) phosphorylation via the MEK-MSK1 signaling pathway. J. Biol. Chem. 2008, 283, 16391-16399. [CrossRef] [PubMed]

41. Lee, Y.; Shin, D.H.; Kim, J.H.; Hong, S.; Choi, D.; Kim, Y.J.; Kwak, M.K.; Jung, Y. Caffeic acid pnenthylester-mediated Nrf2 activation and IkappaB kinase inhibition are involved in NFkappaB inhibitory effect: Structural analysis for NFkappaB inhibition. Eur. J. Pharmacol. 2010, 643, 21-28. [CrossRef]

42. Abduljawad, S.H.; El-Refaei, M.F.; El-Nashar, N.N. Protective and anti-angiopathy effects of caffeic acid phenethyl ester against induced type 1 diabetes in vivo. Int. Immunopharmacol. 2013, 17, 408-414. [CrossRef]

43. Jung, W.K.; Choi, I.; Lee, D.Y.; Yea, S.S.; Choi, Y.H.; Kim, M.M.; Park, S.G.; Seo, S.K.; Lee, S.W.; Lee, C.M.; et al. Caffeic acid phenethyl ester protects mice from lethal endotoxin shock and inhibits lipopolysaccharide-induced cyclooxygenase-2 and inducible nitric oxide synthase expression in RAW 264.7 macrophages via the p38/ERK and NF-kappaB pathways. Int. J. Biochem. Cell. Biol. 2008, 40, 2572-2582. [CrossRef] [PubMed]

44. Toyoda, T.; Tsukamoto, T.; Takasu, S.; Shi, L.; Hirano, N.; Ban, H.; Kumagai, T.; Tatematsu, M. Anti-inflammatory effects of caffeic acid phenethyl ester (CAPE), a nuclear factor-kappaB inhibitor, on Helicobacter pylori-induced gastritis in Mongolian gerbils. Int. J. Cancer 2009, 125, 1786-1795. [CrossRef] [PubMed]

45. Song, Y.S.; Park, E.H.; Hur, G.M.; Ryu, Y.S.; Lee, Y.S.; Lee, J.Y.; Kim, Y.M.; Jin, C. Caffeic acid phenethyl ester inhibits nitric oxide synthase gene expression and enzyme activity. Cancer Lett. 2002, 175, 53-61. [CrossRef]

46. Bezerra, R.M.; Veiga, L.F.; Caetano, A.C.; Rosalen, P.L.; Amaral, M.E.; Palanch, A.C.; de Alencar, S.M. Caffeic acid phenethyl ester reduces the activation of the nuclear factor KB pathway by high-fat diet-induced obesity in mice. Metabolism 2012, 61, 1606-1614. [CrossRef]

47. Carrasco-Legleu, C.E.; Marquez-Rosado, L.; Fattel-Fazenda, S.; Arce-Popoca, E.; Perez-Carreon, J.I.; Villa-Trevino, S. Chemoprotective effect of caffeic acid pnenethyl ester on promotion in a medium-term rat hepatocarcinogenesis assay. Int. J. Cancer 2004, 108, 488-492. [CrossRef]

48. Mapesa, J.O.; Waldschmitt, N.; Schmoeller, I.; Blume, C.; Hofmann, T.; Mahungu, S.; Clavel, T.; Haller, D. Catechols in caffeic acid phenethyl ester are essential for inhibition of independent mechanisms in mouse intestinal epithelial cells. Mol. Nutr. Food Res. 2011, 55, 1850-1861. [CrossRef]

49. Andrade-Silva, A.R.; Ramalho, F.S.; Ramalho, L.N.; Saavedra-Lopes, M.; Jordao, A.A., Jr.; Vanucchi, H.; Piccinato, C.E.; Zucoloto, S. Effect of NFkappaB inhibition by CAPE on skeletal muscle ischemia-reperfusion injury. J. Surg. Res. 2009, 153, $254-262$. [CrossRef] [PubMed]

50. Yilmaz, A.; Yildirim, O.; Tamer, L.; Oz, O.; Cinel, L.; Vatansever, H.; Degirmenci, U.; Kanik, A.; Atik, U. Effects of caffeic acid phenthyl ester on endotoxin-induced uveitis in rats. Curr. Eye. Res. 2005, 30, 755-762. [CrossRef]

51. Abu-Seida, A.M. Effect of Propolis on Experimental Cutaneous Wound Healing in Dogs. Vet. Med. Int. 2015, $2015,672643$. [CrossRef]

52. Olczyk, P.; Wisowski, G.; Komosinska-Vassev, K.; Stojko, J.; Klimek, K.; Olczyk, M.; Kozma, E.M. Propolis Modifies Collagen Types I and III Accumulation in the Matrix of Burnt Tissue. Evid. Based Complement. Alternat Med. 2013, 2013, 423809. [CrossRef]

53. Oryan, A.; Alemzadeh, E.; Moshiri, A. Potential role of propolis in wound healing: Biological properties and therapeutic activities. Biomed Pharmacother. 2017, 98, 469-483. [CrossRef]

54. Martinotti, S.; Ranzato, E. Propolis: A new frontier for wound healing? Burns Trauma 2015, 3, 9. [CrossRef]

55. Kabała-Dzik, A.; Rzepecka-Stojko, A.; Kubina, R.; Jastrzębska-Stojko, Ż.; Stojko, R.; Wojtyczka, R.D.; Stojko, J. Migration Rate Inhibition of Breast Cancer Cells Treated by Caffeic Acid and Caffeic Acid Phenethyl Ester: An In Vitro Comparison Study. Nutrients 2017, 9, 1144. [CrossRef] [PubMed]

56. Olczyk, P.; Ramos, P.; Komosinska-Vassev, K.; Stojko, J.; Pilawa, B. Positive effect of Propolis on Free Radicals in Burn Wounds. Evid. Based Complement. Alternat Med. 2013, 2013, 356737. [CrossRef] [PubMed]

57. Olczyk, P.; Mencner, Ł.; Komosinska-Vassev, K. The role of the extracellular matrix components in cutaneous wound healing. Biomed. Res. Int. 2014, 2014, 747584. [CrossRef]

58. Wu, Y.; Chen, S. Apoptotic cell: Linkage of inflammation and wound healing. Front. Pharmacol. 2014, 5, 1. [CrossRef] [PubMed] 
59. Reinke, J.M.; Sorg, H. Wound repair and regeneration. Eur. Sur. Res. 2012, 49, 35-43. [CrossRef]

60. Nauta, A.; Gurtner, G.C.; Longaker, M.T. Wound healing and regenerative strategies. Oral. Dis. 2011, 17, 541-549. [CrossRef]

61. Dulmovits, B.M.; Herman, I.M. Microvascular remodeling and wound healing: A role for pericytes. Int. J. Biochem. Cell Biol. 2012, 44, 1800-1812. [CrossRef]

62. Romana-Souza, B.; Dos Santos, J.S.; Monte-Alto-Costa, A. Caffeic Acid Phenethyl Ester Promotes Wound Healing of Mice Pressure Ulcers Affecting NF-kB, NOS2 and NRF2 Expression. Life Sci. 2018, 15, 158-165. [CrossRef]

63. Serarslan, G.; Altuğ, E.; Kontas, T.; Atik, E.; Avci, G. Caffeic acid phenethyl ester accelerates cutaneous wound healing in a rat model and decreases oxidative stress. Clin. Exp. Dermatol. 2007, 32, 709-715. [CrossRef] [PubMed]

64. Pittalà, V.; Salerno, L.; Romeo, G.; Acquaviva, R.; di Giacomo, C.; Sorrenti, V. Therapeutic Potential of Caffeic Acid Phenethyl Ester (CAPE) in Diabetes. Curr. Med. Chem. 2018, 25, 4827-4836.

65. Sorrenti, V.; Raffaele, M.; Vanella, L.; Acquaviva, R.; Salerno, L.; Pittalà, V.; Intagliata, S.; Giacomo, C.D. Protective Effects of Caffeic Acid Phenethyl Ester (CAPE) and Novel Cape Analogue as Inducers of Heme Oxygenase-1 in Streptozotocin-Induced Type 1 Diabetic Rats. Int. J. Mol. Sci. 2019, 20, 2441. [CrossRef]

66. Hassan, N.A.; El-Bassossy, H.M.; Mahmoud, M.F.; Fahmy, A. Caffeic acid phenethyl ester, a 5-lipoxygenase enzyme inhibitor, alleviates diabetic atherosclerotic manifestations: Effect on vascular reactivity and stiffness. Chem. Biol. Interact. 2014, 213, 28-36. [CrossRef]

67. Vanella, L.; Tibullo, D.; Godos, J.; Pluchinotta, F.R.; Di Giacomo, C.; Sorrenti, V.; Acquaviva, R.; Russo, A.; Li Volti, G.; Barbagallo, I. Caffeic Acid Phenethyl Ester Regulates PPAR's Levels in Stem Cells-Derived Adipocytes. PPAR Res. 2016, $2016,7359521$. [CrossRef]

68. Andrade-Oliveira, V.; Câmara, N.O.; Moraes-Vieira, P.M. Adipokines as drug targets in diabetes and underlying disturbances. J. Diabetes Res. 2015, 2015, 11. [CrossRef]

69. Langin, D. Adipose tissue lipolysis as a metabolic pathway to define pharmacological strategies against obesity and the metabolic syndrome. Pharmacol. Res. 2006, 53, 482-491. [CrossRef]

70. Choi, J.H.; Choi, S.-S.; Kim, E.S.; Jedrychowski, M.P.; Yang, Y.R.; Jang, H.-J.; Suh, P.-G.; Banks, A.S.; Gygi, S.P.; Spielgman, B.M. Thrap3 docks on phosphoserine 273 of PPAR $\gamma$ and controls diabetic gene programming. Genes Dev. 2014, 28, $2361-2369$. [CrossRef]

71. Yasui, N.; Nishiyama, E.; Juman, S.; Negishi, H.; Miki, T.; Yamori, Y.; Ikeda, K. Caffeic acid phenethyl ester suppresses oxidative stress in 3T3-L1 adipocytes. J. Asian Nat. Prod. Res. 2013, 15, 1189-1196. [CrossRef]

72. Huang, M.T.; Ma, W.; Yen, P.; Xie, J.G.; Han, J.; Frenkel, K. Inhibitory effects of caffeic acid phenethyl ester (CAPE) on 12-Otetradecanoylphorbol-13-acetate-induced tumor promotion in mouse skin and the synthesis of DNA, RNA and protein in HeLa cells. Carcinogenesis 1996, 17, 761-765. [CrossRef] [PubMed]

73. Chen, M.; Chang, W.H.; Lin, C.C.; Liu, C.Y.; Wang, T.E.; Chu, C.H. Caffeic acid phenethyl ester induces apoptosis of human pancreatic cancer cells involving caspase and mitochondrial dysfunction. Pancreatology 2008, 8, 566-576. [CrossRef] [PubMed]

74. Roos, T.U.; Heiss, E.H.; Schwaiberger, A.V.; Schachner, D.; Sroka, I.M.; Oberan, T. Caffeic acid phenethyl ester inhibits PDGFinduced proliferation of vascular smooth muscle cells via activation of p38 MAPK, HIF-1alpha, and heme oxygenase-1. J. Nat. Prod. 2011, 74, 352-356. [CrossRef] [PubMed]

75. Basini, G.; Baioni, L.; Bussolati, S.; Grasselli, F.; Daquino, C.; Spatafora, C. Antiangiogenic properties of an unusual benzo[k,l] xanthene lignan derived from CAPE (caffeic acid phenethyl ester). Invest. New Drugs. 2010, 30, 186-190. [CrossRef]

76. Matsunaga, T.; Tsuchimura, S.; Azuma, N.; Endo, S.; Ichihara, K.; Ikari, A. Caffeic acid phenethyl ester potentiates gastric cancer cell sensitivity to doxorubicin and cisplatin by decreasing proteasome function. Anticancer Drugs 2019, 30, 251-259. [CrossRef] [PubMed]

77. Solar, P.; Sytkowski, A.J. Differentially expressed genes associated with cisplatin resistance in human ovarian adenocarcinoma cell line A2780. Cancer Lett. 2011, 309, 11-18. [CrossRef] [PubMed]

78. Gherman, C.; Braicu, O.L.; Zanoaga, O.; Jurj, A.; Pileczki, V.; Maralani, M.; Drigla, F.; Braicu, C.; Budisan, L.; Achimas-Cadariu, P.; et al. Caffeic acid phenethyl ester activates pro-apoptotic and epithelial-mesenchymal transition-related genes in ovarian cancer cells A2780 and A2780cis. Mol. Cell Biochem. 2016, 413, 189-198. [CrossRef]

79. Tani, H.; Hasumi, K.; Tatefuji, T.; Hashimoto, K.; Koshino, H.; Takahashi, S. Inhibitory activity of Brazilian green propolis components and their derivatives on the release of cys-leukotrienes. Bioorg. Med. Chem. 2010, 18, 151-157. [CrossRef]

80. Moura, S.A.; Negri, G.; Salatino, A.; Lima, L.D.; Dourado, L.P.; Mendes, J.B. Aqueous extract of Brazilian green propolis: Primary components, evaluation of inflammation and wound healing by using subcutaneous implanted sponges. Evid. Based Complement. Alternat Med. 2011, 2011, 748283. [CrossRef]

81. Lin, H.P.; Jiang, S.S.; Chuu, C.P. Caffeic acid phenethyl ester causes p21 induction, Akt signaling reduction, and growth inhibition in PC-3 human prostate cancer cells. PLoS ONE 2012, 7, 31286.

82. Tolba, M.F.; Esmat, A.; Al-Abd, A.M.; Azab, S.S.; Khalifa, A.E.; Mosli, H.A. Caffeic acid phenethyl ester synergistically enhances docetaxel and paclitaxel cytotoxicity in prostate cancer cells. IUBMB Life 2013, 65, 716-729. [CrossRef] [PubMed]

83. Breitzig, M.; Bhimineni, C.; Lockey, R.; Kolliputi, N. 4-Hydroxy-2-nonenal: A critical target in oxidative stress? Am. J. Physiol. Cell Physiol. 2016, 311, C537-C543. [CrossRef] 
84. Soda, M.; Hu, D.; Endo, S.; Takemura, M.; Li, J.; Wada, R. Design, synthesis and evaluation of caffeic acid phenethyl ester-based inhibitors targeting a selectivity pocketin the active site of human aldo-keto reductase 1B10. Eur. J. Med. Chem. 2012, 48, 321-329. [CrossRef]

85. Sonoki, H.; Tanimae, A.; Furuta, T.; Endo, S.; Matsunaga, T.; Ichihara, K.; Ikari, A. Caffeic acid phenethyl ester down-regulates claudin-2 expression at the transcriptional and post-translational levels and enhances chemosensitivity to doxorubicin in lung adenocarcinoma A549 cells. J. Nutr. Biochem. 2018, 56, 205-214. [CrossRef]

86. Kuo, Y.Y.; Jim, W.T.; Su, L.C.; Chung, C.J.; Lin, C.Y.; Huo, C.; Tseng, J.C.; Huang, S.H.; Lai, C.J.; Chen, B.C.; et al. Caffeic Acid phenethyl ester is a potential therapeutic agent for oral cancer. Int. J. Mol. Sci. 2015, 12, 10748-10766. [CrossRef]

87. Kuo, Y.Y.; Lin, H.P.; Huo, C.; Su, L.C.; Yang, J.; Hsiao, P.H.; Chiang, H.C.; Chung, C.J.; Wang, H.D.; Chang, J.Y. Caffeic acid phenethyl ester suppresses proliferation and survival of TW2.6 human oral cancer cells via inhibition of Akt signaling. Int. J. Mol. Sci. 2013, 14, 8801-8817. [CrossRef]

88. Motawi, T.K.; Abdelazim, S.A.; Darwish, H.A.; Elbaz, E.M.; Shouman, S.A. Could Caffeic Acid Phenethyl Ester Expand the Antitumor Effect of Tamoxifen in Breast Carcinoma? Nutr. Cancer 2016, 68, 435-445. [CrossRef]

89. Chuu, C.P.; Lin, H.P.; Ciaccio, M.F.; Kokontis, J.M.; Hause, R.J., Jr.; Hiipakka, R.A.; Liao, S.; Jones, R.B. Caffeic acid phenethyl ester suppresses the proliferation of human prostate cancer cells through inhibition of p70S6K and Akt signaling networks. Cancer Prev. Res. 2012, 5, 788-797. [CrossRef]

90. Risau, W. Mechanisms of angiogenesis. Nature 1997, 386, 671-674. [CrossRef]

91. Michalski, B.; Banys, A.; Drosdzol, A.; Skrzypulec, V.; Mazurek, U. Komórka niedotleniona celem dla terapii selektywnej w onkologii. The hypoxic cell a target for selective cancer therapy. Przegląd Menopauzalny 2009, 4, 196-201.

92. Ferrara, N.; Gerber, H.P.; LeCouter, J. The biology of VEGF and its receptors. Nat. Med. 2003, 9, 669-676. [CrossRef]

93. Banys, A.; Orchel, J.; Mazurek, U.; Michalski, B.; Drosdzol, A.; Skrzypulec, V.; Jankowski, A. Aktywność trakrypcyjna genów szlaków sygnalizacyjnych receptora VEGFR-2 w raku szyjki macicy wyznaczona technika mikromacierzy oligonukleotydowych. Transcription activity of the signaling pathway genes of VEGFR-2 in cervical cancer determined with the oligonucleotide microarray technique. Przeglad Menopauzalny 2009, 2, 72-75.

94. El-Refaei, M.F.; El-Naa, M.M. Inhibitory effect of caffeic acid phenethyl ester on mice bearing tumor involving angiostatic and apoptotic activities. Chem. Biol. Interact 2010, 186, 152-156. [CrossRef]

95. Huang, S.; Robinson, J.B.; Deguzman, A.; Bucana, C.D.; Fidler, I.J. Blockade of nuclear factor-kappa B signaling inhibits angiogenesis and tumorigenicity of human ovarian cancer cells by suppressing expression of vascular endothelial growth factor and interleukin 8. Cancer Res. 2000, 60, 5334-5339.

96. Huang, S.; Pettaway, C.A.; Uehara, H.; Bucana, C.D.; Fidler, I.J. Blockade of NF-KB activity in human prostate cancer cells is associated with suppression of angiogenesis, invasion, and metastasis. Oncogene 2001, 20, 4188-4197. [CrossRef]

97. Paeng, S.H.; Jung, W.K.; Park, W.S.; Lee, D.S.; Kim, G.Y.; Choi, Y.H.; Seo, S.K.; Jang, W.H.; Choi, J.S.; Lee, Y.M. Caffeic acid phenethyl ester reduces the secretion of vascular endothelial growth factor through the inhibition of the ROS, PI3K and HIF-1 $\alpha$ signaling pathways in human retinal pigment epithelial cells under hypoxic conditions. Int. J. Mol. Med. 2015, 35, 1419-1426. [CrossRef]

98. Stetler-Stevenson, W.G.; Liotta, L.A.; Kleiner, D.E., Jr. Extracellular matrix 6: Role of matrix metalloproteinases in tumor invasion and metastasis. FASEB J. 1993, 7, 1434-1441. [CrossRef]

99. Egeblad, M.; Werb, Z. New functions for the matrix metalloproteinases in cancer progression. Nat. Rev. Cancer 2002, 2, 161-174. [CrossRef]

100. Chou, Y.C.; Sheu, J.R.; Chung, C.L.; Chen, C.Y.; Lin, F.L.; Hsu, M.J.; Kuo, Y.H.; Hsiao, G. Nuclear-targeted inhibition of NF-кB on MMP-9 production by N-2-(4-bromophenyl) ethyl caffeamide in human monocytic cells. Chem. Biol. Interact 2010, 184, 403-412. [CrossRef]

101. Brew, K.; Dinakarpandian, D.; Nagase, H. Tissue inhibitors of metalloproteinases: Evolution, structure and function. Biochim. Biophys. Acta. 2000, 1477, 267-283. [CrossRef]

102. Bode, W.; Fernandez-Catalan, C.; Grams, F.; Gomis-Ruth, F.X.; Nagase, H.; Tschesche, H.; Maskos, K. Insights into MMP-TIMP interactions. Ann. N. Y. Acad. Sci. 1999, 878, 73-91. [CrossRef]

103. Nelson, A.R.; Fingleton, B.; Rothenberg, M.L.; Matrisian, L.M. Matrix metalloproteinases: Biologic activity and clinical implications. J. Clin. Oncol. 2000, 18, 1135-1149. [CrossRef]

104. Bjorklund, M.; Koivunen, E. Gelatinase-mediated migration and invasion of cancer cells. Biochim. Biophys. Acta 2005, 1755, 37-69. [CrossRef]

105. Peng, C.Y.; Yang, H.W.; Chu, Y.H.; Chang, Y.C.; Hsieh, M.J.; Chou, M.Y.; Yeh, K.T.; Lin, Y.M.; Yang, S.F.; Lin, C.W. Caffeic acid phenethyl ester inhibits oral cancer cell metastasis by regulating matrix metalloproteinase-2 and the mitogen-activated protein kinase pathway. Evid. Based Complement. Altern. Med. 2012, 2012, 732578. [CrossRef]

106. Chan, G.; Boyle, J.O.; Yang, E.K.; Zhang, F.; Sacks, P.G.; Shah, J.P.; Edelstein, D.; Soslow, R.A.; Koki, A.T.; Woerner, B.M. Cyclooxygenase-2 expression is up-regulated in squamous cell carcinoma of the head and neck. Cancer Res. 1999, 59, 991-994.

107. Sudbo, J.; Ristimaki, A.; Sondresen, J.E.; Kildal, W.; Boysen, M.; Koppang, H.S.; Reith, A.; Risberg, B.; Nesland, J.M.; Bryne, M. Cyclooxygenase-2 (COX-2) expression in high-risk premalignant oral lesions. Oral Oncol. 2003, 39, 497-505. [CrossRef]

108. Sakurai, K.; Urade, M.; Noguchi, K.; Hashitani, S.; Takaoka, K.; Segawa, E.; Kishimoto, H. Prognostic significance of cyclooxygenase-2 and DNA topoisomerase II $\alpha$ expression in oral carcinoma. Head Neck. 2007, 29, 1002-1009. [CrossRef] 
109. Michaluart, P.; Masferrer, J.L.; Carothers, A.M.; Subbaramaiah, K.; Zweifel, B.S.; Koboldt, C.; Mestre, J.R.; Grunberger, D.; Sacks, P.G.; Tanabe, T. Inhibitory effects of caffeic acid phenethyl ester on the activity and expression of cyclooxygenase-2 in human oral epithelial cells and in a rat model of inflammation. Cancer Res. 1999, 59, 2347-2352.

110. Kızıldă̆, A.; Arabacı, T.; Albayrak, M.; Taşdemir, U.; Şenel, E.; Dalyanoglu, M.; Demirci, E. Therapeutic effects of caffeic acid phenethyl ester on alveolar bone loss in rats with endotoxin-induced periodontitis. J. Dent. Sci. 2019, 14, 339-345. [CrossRef]

111. Araujo, A.A.; Souza, T.O.; Moura, L.M. Effect of telmisartan on levels of IL-1, TNF-alpha, down-regulated COX-2, MMP-2, MMP-9 and RANKL/RANK in an experimental periodontitis model. J. Clin. Periodontol. 2013, 40, 1104-1111. [CrossRef]

112. Kazancioglu, H.O.; Bereket, M.C.; Ezirganli, S.; Aydin, M.S.; Aksakalli, S. Effects of caffeic acid phenethyl ester on wound healing in calvarial defects. Acta Odontol. Scand. 2015, 73, 21-27. [CrossRef]

113. Kazancioglu, H.O.; Aksakalli, S.; Ezirganli, S.; Birlik, M.; Esrefoglu, M.; Acar, A.H. Effect of caffeic acid phenethyl ester on bone formation in the expanded inter-premaxillary suture. Drug Des. Dev. Ther. 2015, 9, 6483-6488. [CrossRef]

114. Kumar, M.; Kaur, D.; Bansal, N. Caffeic Acid Phenethyl Ester (CAPE) Prevents Development of STZ-ICV Induced dementia in Rats. Pharmacogn. Mag. 2017, 13, S10-S15. [PubMed]

115. Aljuffali, I.A.; Fang, C.-L.; Chen, C.-H.; Fang, J.-Y. Nanomedicine as a strategy for natural compound delivery to prevent and treat cancers. Curr. Pharm Des. 2016, 22, 4219-4231. [CrossRef] [PubMed]

116. Tambuwala, M.M.; Khan, M.N.; Thompson, P.; McCarron, P.A. Albumin nano-encapsulation of caffeic acid phenethyl ester and piceatannol potentiated its ability to modulate HIF and NF-kB pathways and improves therapeutic outcome in experimental colitis. Drug Deliv. Transl. Res. 2019, 9, 14-24. [CrossRef] [PubMed]

117. Walgrave, S.E.; Warshaw, E.M.; Glesne, L.A. Allergic contact dermatitis from propolis. Dermatitis 2005, 16, $209-215$.

118. Cornara, L.; Biagi, M.; Xiao, J.; Burlando, B. Therapeutic Properties of Bioactive Compounds from Different Honeybee Products. Front. Pharmacol 2017, 8, 412. [CrossRef] [PubMed]

119. Olczyk, P.; Komosinska-Vassev, K.; Krzyminiewski, R.; Kasperczyk, J.; Ramos, P.; Dobosz, B.; Batoryna, O.; Stojko, J.; Stojko, M.; Ivanova, D.; et al. The Estimation of Blood Paramagnetic Center Changes during Burns Management with Biodegradable Propolis-Nanofiber Dressing. Oxid. Med. Cell Longev. 2020, 28, 3675603. 